\title{
The Know Nothings Nobody Knows: Political Nativists in Antebellum Iowa
}

\author{
ROBERT R. DYKSTRA
}

THE KNOW NOTHING MOVEMENT emerged in the 1850 s. It had as its goal the preservation of American democracy from the rising political influence of recent immigrants and Roman Catholics-especially immigrant Irish Catholics. Know Nothings were pledged to keep their activities secret; according to legend they were expected to disavow their affiliation to outsiders-as in, "I know nothing about it." By 1853 they had come to be called "Know Nothings," a label they themselves embraced as nicely reflecting the mystery surrounding their activities. Later, when they felt strong enough to openly form their own national political organization, the American party, they came to prefer being called "the Americans." ${ }^{1}$

Historians of antebellum politics in the United States have become increasingly interested in the Know Nothings because of their apparent role in the breakup of the Whig party in the 1850 s and the rise of the Republican party. But all of this new interest has virtually overlooked Know

An earlier version of this article was presented at the Congress of Historical Organizations in Des Moines on June 16, 1993. I wish to thank Marvin Bergman, Ronald F. Matthias, and Lowell J. Soike for graciously furnishing me materials employed in revising the original.

1. Tyler Anbinder, Nativism and Slavery: The Northern Know Nothings and the Politics of the 1850s (New York, 1992), ix, 20-22, says that the traditional story about the origin of the term Know Nothing cannot be verified.

THE ANNALS OF IOWA 53 (Winter 1994). CThe State Historical Society of Iowa, 1994. 
Nothing activity in the Hawkeye state. ${ }^{2}$ That is understandable: Iowa's historians have published almost nothing on its Know Nothing movement. ${ }^{3}$ There is no book on the Iowa Know Nothings, although two unpublished fulllength works exist. ${ }^{4}$ All that is to be found in the state his-

2. Thus the latest book, Anbinder's Nativism and Slavery, has this to say: "Although Democrats made claims to the contrary, Know Nothings did not form their first lodge in Iowa until July 26, just twelve days before the [1854] election, so the Order had little impact on the election there" (55). On other pages it briefly mentions "Know Nothing congressman James Thorington of Iowa" (201) and "Iowa's William Penn Clarke" (209). Except for a few passing references $(23,167,210,216)$, that is it. Anbinder's prize-winning book is only the latest monograph. Important political studies reflecting the attention to the Know Nothings that began in the late 1960s include Michael Fitzgibbon Holt, Forging a Majority: The Formation of the Republican Party in Pittsburgh, 18481860 (New Haven, 1969); Ronald P. Formisano, The Birth of Mass Political Parties: Michigan, 1827-1861 (Princeton, 1971); Michael F. Holt, The Political Crisis of the 1850s (New York, 1978); Paul Kleppner, The Third Electoral System, 1853-1892: Parties, Voters, and Political Cultures (Chapel Hill, NC, 1979); Dale Baum, The Civil War Party System: The Case of Massachusetts, 1848-1876 (Chapel Hill, NC, 1984); William E. Gienapp, The Origins of the Republican Party, 1852-1856 (New York, 1987).

3. Various bibliographies and the cumulative indexes to the Annals of Iowa, the Iowa Historical Record, and the Iowa Journal of History and Politics demonstrate that Know Nothing references, with a few small exceptions, concern the national-not the Iowa-movement. See Jacob Van der Zee, ed., Index to the Annals of Iowa ... 1863-1874 (Iowa City, 1975), 295; Charles Aldrich, ed., Annals of Iowa [Index:] April, 1893-January, 1909 (Des Moines, 1912), 123; Edgar R. Harlan, ed., Annals of Iowa [Index:] April, 1909-April, 1929 (Des Moines, 1931), 79; [Ora Williams, ed.,] Annals of Iowa [Index:] July, 1929-April, 1947 (Des Moines, 1947), 32; Marvin Bergman, ed., The Annals of Iowa: Cumulative Index, Volumes 29-50, 1947-1991 (Iowa City, 1993), 102; Jacob A. Swisher, ed., Index to the Iowa Historical Record: ... 1885-1902 (Iowa City, 1975), 390; Ruth A. Gallaher, The Iowa Journal of History and Politics: Cumulative Index . . . 1903-1942, 5 vols. (Iowa City, 1944-1946), 3:7475; William J. Petersen, ed., Iowa History Reference Guide (Iowa City, 1952), 75; Patricia Dawson and David Hudson, comps., Iowa History and Culture: A Bibliography of Materials Published between 1952 and 1986 (Ames, 1989), 178. In addition, the unindexed Annals of Iowa, 2d ser., 1-3 (1882-1884), contains no Know Nothing material. A single lengthy article, Ira Cross's "The Origin, Principles, and History of the American Party," Iowa Journal of History and Politics 4 (1906), 526-53, is an overview of the larger movement.

4. The first is a master's thesis of limited usefulness: Willard Irving Toussaint, "The Know Nothing Party in Iowa" (M.A. thesis, University of Iowa, 1956). No less than one-third of its text merely summarizes national political events, and it contains the mistaken assertion (36) that only one 
torical journals are a few scattered memoirs of local activity that are far too brief to be of much substantive use. ${ }^{5} \mathrm{~A}$ meticulous survey of nineteenth-century county histories might unearth similar snippets, but they would hardly add up to a coherent treatment. ${ }^{6}$ Although Hawkeyes were evidently very active in the movement, they remain the Know Nothings nobody knows.

This essay seeks to kindle scholarly interest in Iowa's Know Nothings. It does so by providing an up-to-date historiographical context for the Iowa movement, by constructing a summary narrative of what is known of the movement's brief career and of those involved as its leaders, and by offering a new assessment of grass-roots American party voters in Iowa, their political and social origins, and their numerical strength.

Know Nothing lodge was ever established in the Hawkeye state. But the second unpublished study, Ronald F. Matthias, "The Know Nothing Movement in Iowa" (Ph.D. diss., University of Chicago, 1965) is an excellent treatment of the Iowa movement based on painstaking research in newspapers and letter collections and a judicious visual examination of election returns. That Matthias's manuscript remains unpublished is perhaps the main reason the Iowa Know Nothings are the Know Nothings nobody knows. Morton M. Rosenberg, Iowa on the Eve of the Civil War: A Decade of Frontier Politics (Norman, OK, 1972), 242, for example, overlooks Matthias entirely.

5. Hosea Horn, "History of Davis County, Iowa," Annals of Iowa, 1st ser., 4 (1866), 658, 693-95, 697; William H. Tuthill, "The Garry Owen Vote," ibid. 8 (1870), 217-20; D. C. Bloomer, "Notes on the History of Pottawattamie County," ibid. 10 (1872), 128-29; C. C. Nourse, "Beginning Fifty Years of Practice at the Iowa Bar," ibid., 3d ser., 8 (1908), 491-92; Charles J. Fulton, "Jefferson County Politics before the Civil War," ibid. 11 (1914), 437-53; L. O. Leonard, "The Know Nothing Party in Des Moines County," ibid. 19 (1934), 187-88. Curiously, L. O. Leonard's article is reprinted-but with authorship ascribed to Nathan R. Leonard-in "Notes and Comment," Iowa Journal of History and Politics 38 (1940), 332-34.

6. The best example I have seen is a nineteenth-century account included in a more recently published work: Edna L. Jones, ed., Nathan Littler's History of Washington County, 1835-1875 (Washington, 1977), 151-53, 176-78. Unfortunately, the text of the first citation is garbled. Line 50 of p. 151"It was" - ends abruptly but is continued on line 39 of p. 152: "during the first year of the Know Nothing excitement which ran like wild fire all over our country." On line 29 of p. 153 the text- "Nearly all the Democrats" reverts back to line 50 of p. 151: "together with a great body of the Whigs voted the Know Nothing ticket." 
THE SUMMER OF 1854 was an exciting moment in the Hawkeye state. By electing Burlington's James W. Grimes as their governor, voters would overthrow a reactionary Democratic political machine that had ruled Iowa since its earliest existence as a territory. Representing an intricate fusion of the state's Free Soil party and its Whig party, the Grimes coalition was known as an "Anti-Nebraska" ticket because of its opposition to the Kansas-Nebraska Act permitting the spread of slavery into the trans-Missouri West. In the August 7 election the Anti-Nebraskans carried not only the governorship but also one of Iowa's two congressional seats, the state auditor's office, and a majority of the seats in the General Assembly. That legislature then held a controversial election (as was the practice in those days before the direct election of senators) and named an Anti-Nebraskan, James Harlan, to the U.S. Senate. It was a stunning triumph in the northern states' eight-year fight against slavery extension. ${ }^{7}$

In hindsight, the signs in Iowa as elsewhere pointed toward the reorganization of such antiextension state parties into a national Republican party committed to stemming the spread of slavery. Governor-elect Grimes was only one of many northern political leaders with that goal in mind. But throughout the North others entertained an alternate vision. They would co-opt all of this antiextension energy for Know Nothingism - that is, they hoped to create a movement that, while primarily nativist, would also be antislavery, curbing both slavery extension and the political influence of immigrants and Catholics. ${ }^{8}$

The recruitment of Know Nothings in America peaked at about the time of Grimes's election. Writing two years later, Thomas R. Whitney of New York, a prominent American party spokesman, revealed that Iowa's first Know Nothing lodge had been organized in late July 1854 . Whitney does not

7. Robert R. Dykstra, Bright Radical Star: Black Freedom and White Supremacy on the Hawkeye Frontier (Cambridge, 1993), 115-17, 126-27. Matthias favors the term Opposition for the Grimes coalition, which some historians have argued its members called themselves. I prefer the term that became the accepted name in several states.

8. Anbinder, Nativism and Slavery, especially 44-50; Matthias, "Know Nothing Movement," 80-83. 
say where. Perhaps it was in Muscatine, where the attempt to keep saloons from being licensed had generated political conflict between reformers and German immigrants, and where Iowa's only chapter of the United Sons of America, an older nativist society, had been formed in 1852 . Or perhaps it was in Dubuque, where on July 1, 1854, a British-born physician began issuing a scurrilous little anti-Catholic newspaper, the Dubuque Weekly Observer. ${ }^{9}$

On October 4, 1854, under the guise of meeting to form a liquor prohibition society, nativists from several eastern Iowa counties met in Davenport to form an Iowa Grand Council. By the end of October, local lodges were active in Dubuque, Marion, Muscatine, and West Point. By December at least five Iowa newspapers-the Albia Independent Press, the Dubuque Observer, the Des Moines Valley Whig (Keokuk), the Muscatine Journal, and the Tipton Advertiser-editorially supported the order. Three more-the Davenport Gazette, the Dubuque Tribune, and the Iowa City Republican-followed suit early in 1855. Know Nothingism had begun to take a toll among Democrats as well as former Whigs, one alleged defector being chairman of the state Democratic central committee. At some point Iowa's new congressman, James Thorington, who had been elected on the Anti-Nebraska ticket, was initiated into the order and became secretary of its Iowa Grand Council. ${ }^{10}$

A second-generation Irish immigrant of Protestant background, Thorington was born in North Carolina and grew up on the Alabama frontier. After three years at the University of Alabama, he read law with his attorney father and then spent two exciting seasons in the Rocky Mountains with a

9. Anbinder, Nativism and Slavery, 42; Thomas R. Whitney, A Defence of the American Policy, as Opposed to the Encroachments of Foreign Influence, and Especially to the Interference of the Papacy in the Political Interests and Affairs of the United States (New York, 1856), 284; Matthias, "Know Nothing Movement," 4-7, 73, 76n. Joseph Eiboeck, who grew up in Iowa's most Catholic city, recalled witnessing a fistfight between the Observer editor and the very partisan Democratic editor of Dubuque's Express and Herald. Toussaint, "Know-Nothing Party," 43-44.

10. Matthias, "Know Nothing Movement," 1-16, 22-23, 27-28. Whitney, Defence of the American Policy, 284, dates the organization of the Iowa council as October 5. 


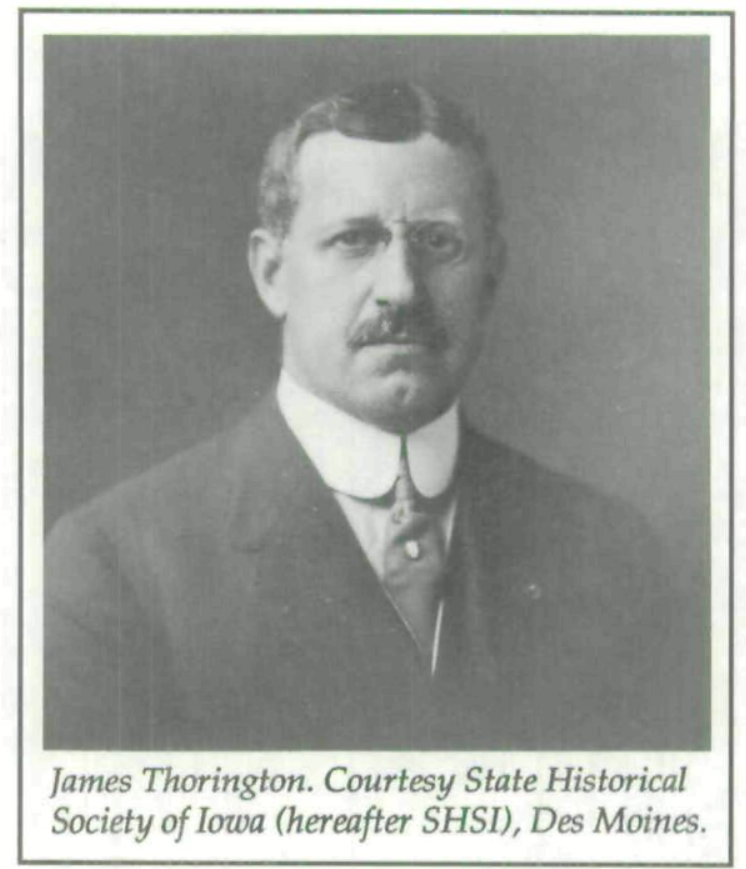

party of fur trappers. The Thorington family moved to Davenport in 1839, where James became a modestly prosperous lawyer and public official, serving multiple terms as mayor, probate judge, sheriff, recorder, and clerk of the district court. In 1854 he was elected to a single term in Congress. "He was not a man of extraordinary ability," it was recalled of Congressman Thorington, "but was a good politician and wirepuller." His most elaborate biography says nothing of his Know Nothing activities. ${ }^{11}$

The state's most politically important Know Nothing was the well-known Iowa City attorney, William Penn Clarke. A Baltimore native, Clarke had arrived in 1844 at what was then Iowa's capital. He became a protégé of the governor, edited a newspaper for a year, served on the territory's Whig

11. Biographical History and Portrait Gallery of Scott County, Iowa (Chicago, 1895), 288-93. The quoted judgment is from History of Butler and Bremer Counties, Iowa (Springfield, IL, 1883), 287. Thorington's wealth is documented and compared to other members of Davenport's elite community in Timothy R. Mahoney, "Down in Davenport: The Social Response of Antebellum Elites to Regional Urbanization," Annals of Iowa 50 (1990), 598 (table 1). 


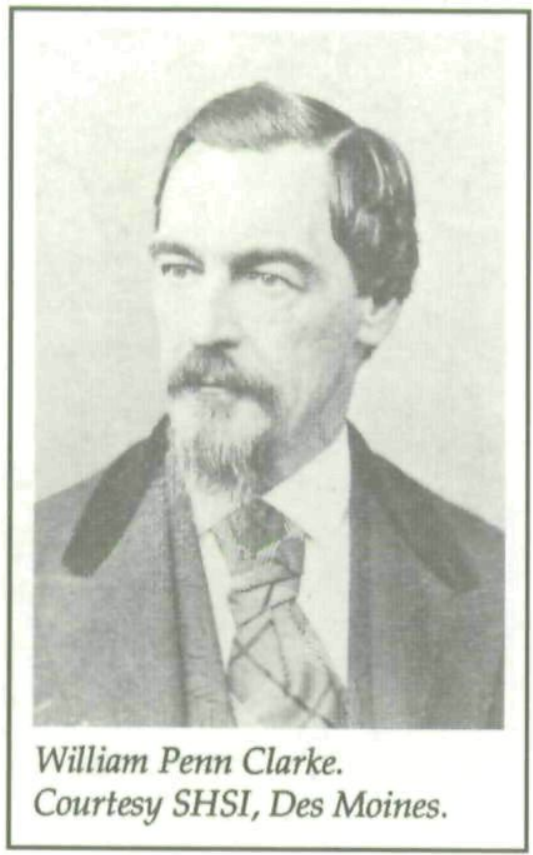

central committee, and read law. A rising figure within Iowa's Whig party, Clarke was the quintessential Whig in many ways. But in September 1848, disgusted with his party's waffling on slavery extension, he defected to the accumulation of abolitionists who made up Iowa's tiny Free Soil movement. The Free Soilers' first "high-profile" acquisition from either major party, Clarke promptly became their most prominent leader. ${ }^{12}$

Unlike the rank and file of his new party, Clarke seems to have imagined actually gaining office and thus fulfilling personal political ambitions as well as helping save the nation from the Slave Power. But it was not to be. The apparent resolution of all slavery issues by the celebrated congressional Compromise of 1850 doomed Iowa's Free Soilers to a continued minor role. By 1852 Clarke had allowed his third-party prominence to lapse, and two years later he was neither a Whig nor a Free Soil activist. He therefore played no part in the Anti-Nebraska triumph that elevated Grimes to the statehouse. But Clarke may well have seen in Know Nothingism a

12. Dykstra, Bright Radical Star, 81-83. 


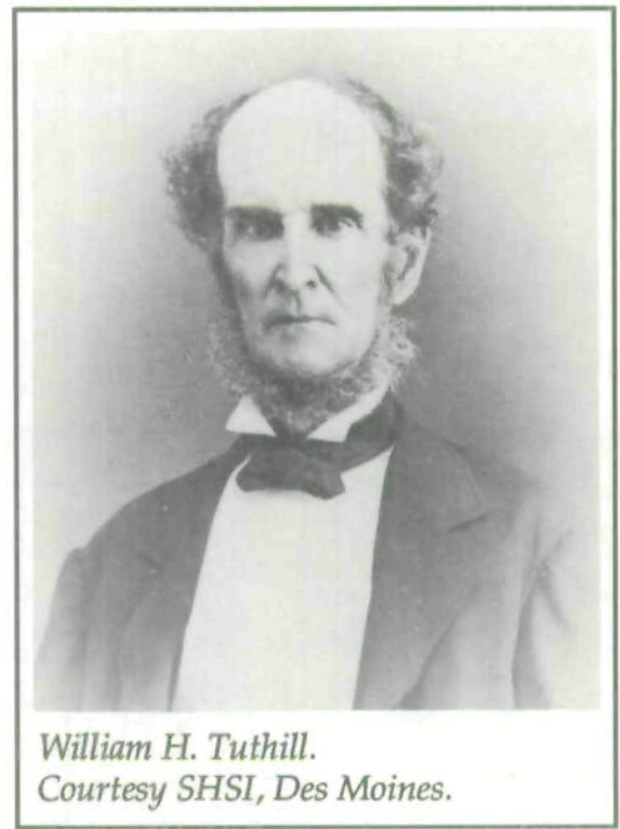

chance for the antislavery coalition to consolidate its political success in a manner that would allow him to capture the leadership of the coalition from the new governor. In any case, five weeks after Grimes's election, Clarke was already at work devising a statewide Know Nothing organization. ${ }^{13}$

Except for Thorington and Clarke, Iowa's Know Nothings were not prominent in Hawkeye politics. Few revealed their membership in the order at the moment it flourished, and few chose to admit it afterward. For example, we know that William H. Tuthill of Tipton was president of Iowa's Know Nothing Council only because he was listed as such on a charter issued to a lodge in Davis County and because an exchange between Thorington and Clarke implicitly confirms it. $^{14}$

Tuthill, descended from the earliest settlers of Long Island, had been born in New York City. After receiving a private-school education, he studied the engraver's trade until

13. Ibid., 106-10, 113, 130; Matthias, "Know Nothing Movement," 11-12. 14. Horn, "History of Davis County," 658; James Thorington to William Penn Clarke, 5 June 1855, Clarke Papers, State Historical Society of Iowa, Des Moines. 
ill health forced him to give it up. During the 1832 cholera epidemic he served as assistant secretary of the New York Board of Health, a position apparently giving him claim to the title "Dr." that appears in one capsule biography. Thereafter he clerked in New York's prestigious Chemical Bank. In 1840 , at age thirty-one, he moved to Iowa, possibly for his health, which was delicate throughout his life. In frontier Tipton he first ran a store, then was admitted to the bar, became active in Whig politics, dabbled briefly in journalism and various commercial enterprises, and served two lackluster terms on the district bench. "Tuthill was not a success as a judge," recalled a contemporary, "and while civil business increased rapidly he was unable to dispose of it." Perhaps the reason was that he had already resumed his true calling as a banker. Other than Tuthill's having been nurtured in the often xenophobic politics of New York City and his evident pride in his Anglo-Saxon Protestant genealogy, there is no explanation for his leadership of the Iowa order. And although he once published a short comic piece on the subject, his biographies studiously overlook his Know Nothing allegiance. ${ }^{15}$

Early in 1855 Tuthill won a special election for judge of the Eighth Judicial District in east-central Iowa. In that year the nation's Know Nothings-following New York State's example-began to field their own slates of candidates for political office. Besides Tuthill, Iowa Know Nothing candidates (in most cases suitably disguised as "independent" or "people's" nominees) won victories that spring in municipal elections in Council Bluffs, Farmington, Keosauqua, Le Claire, Washington, West Point, and-more importantly, because of their size-Davenport, Iowa City, Keokuk, and Muscatine. Know Nothings lost Burlington only because election judges permitted the votes of 150 to 400 unnaturalized aliens to be cast against them. They carried township elections in Burling-

15. The United States Biographical Dictionary: Iowa Volume (Chicago, 1878), 434-35; The History of Cedar County, Iowa (Chicago, 1878), 433-34, 44042, 452, 481, 615; William Graham, quoted in James W. Ellis, History of Jackson County, Iowa, 2 vols. (Chicago, 1910), 1:82; William H. Tuthill, "The Garry Owen Vote," Annals of Iowa, 1st ser., 8 (1870), 217-20. 
ton, Davenport, Muscatine, and Ottumwa. In a special election, a Know Nothing became Des Moines County Recorder and Treasurer. ${ }^{16}$

Despite their successes in local elections, Iowa's Know Nothings still felt unready to go it alone when it came to statewide office. In March 1855 some one hundred delegates from forty counties gathered in Muscatine-again under the guise of a prohibition convention-to plan strategy for the upcoming state contests. In the end they simply endorsed a slate nominated by the Anti-Nebraskans, which (since William Penn Clarke was involved in the process) may have been chosen with eventual Know Nothing support in mind. In the election, this fusion slate, headed by William McKay, candidate for manager of the Des Moines River Improvement Commission, carried all three minor offices at stake. ${ }^{17}$

The New York Herald later claimed that there were 24,743 Know Nothings in Iowa, but that figure was simply McKay's total vote. No more than 20 percent of McKay supporters could have been hard-core Know Nothings-that is, something fewer than the estimated five thousand or so McKay partisans who later voted for the American party's presidential candidate. ${ }^{18}$ Still, although relatively few Democrats voted for the fusion ticket, ten sizable counties-Jackson and Jones in the east, Hardin and Marshall in central Iowa, Pottawattamie on the west, plus five Missouri-border countiesswitched from Democratic to Anti-Nebraska/Know Nothing

16. Anbinder, Nativism and Slavery, 41-42, 78-84; Matthias, "Know Nothing Movement," 25-28, 32, 38-39.

17. Matthias, "Know Nothing Movement," 29-32, 39.

18. Matthias, "Know Nothing Movement," 92. Since no Iowa Know Nothing ran as a candidate independently for statewide office, we have no strict measure of the order's total electoral strength. Based on ecological regression analyses of the 1855 and 1856 elections, we can only say this: in 1856 an estimated 20 percent of William McKay's supporters voted for Millard Fillmore, the American party nominee for president. See Dykstra, Bright Radical Star, 289 (second panel of table B.7), from which Fillmore's designated 5 percent can be recalculated as 20 percent of the total number of 1855 Anti-Nebraska/Know Nothing voters. The regression results underlying table B.7 reveal a more technically precise estimate of 20.013 percent. Therefore, for the raw number of possible Know Nothing voters, the formula is: $.20013 \times 24,743$ (the number of McKay ballots) $=4,952$. 
allegiances. Since all ten counties, says Ronald Matthias, "had, at one time or another, strong Know Nothing organizations," it is plausible that nativists in these locales could boast responsibility for the fusion ticket's popularity. Leading Democrats agreed. "Politically," complained a Keokuk Jacksonian, "we are beaten in all this region by the accursed, secret, oath bound gang, of 'Know Nothings' ... the d------st, \& most atrocious, of all the organized isms we have yet had to contend against." 19

IOWA'S KNOW NOTHINGS, like their counterparts elsewhere, might agree when it came to immigrants, Catholics, and perhaps liquor prohibition, but they varied in the strength of their antislavery impulses. Thus a Burlington newspaper editor explained that he joined the order as a means of intellectually escaping the slavery issue. In 1854, he wrote, "the whole political world being at loose ends, when whigs were whigs no longer, when democrats were holding the knife to each others throats over the Nebraska bill, and when rumor whispered that there was a great national conservative party growing up, composed of the better men and sounder patriotism of both the old parties, I submitted to an initiation." (Such escapism, as Matthias suggests, may well have motivated the heavily southern-born Know Nothings of the Missouri-border counties fearful of a sectional civil war. And perhaps it is no coincidence that both William Penn Clarke and James Thorington had been born and raised in slave states.) But Tipton's Know Nothing editor, Wells Spicer, explained the ultimate political position of men like himself, Clarke, and Thorington. "Upon the slavery question we ... are Anti-Nebraska," he said, "first, last and all the time-are opposed to the extension of slavery-opposed to its existence." As an Oskaloosa Know Nothing asserted, "I am an American, and expect to stick to that party \& its principles,

19. Dykstra, Bright Radical Star, 289 (table B.6); Matthias, "Know Nothing Movement," 40-43; Ver Planck Van Antwerp to Laurel Summers, 5 April 1855, quoted ibid., 43. 
but I will not vote for any man who is not opposed to the extension of Slavery." 20

Could Iowans of such widely differing shades of opinion be kept together in a single political movement? Not likely, given the drumbeat for repeal of the Kansas-Nebraska Act that grew more intense around the nation as 1855 wore on. Anti-Nebraskans everywhere, including Iowa's Governor Grimes, prepared to co-opt the Know Nothings into a new Republican party. Events played into their hands.

As early as the end of May 1855, Iowa's Know Nothing press seemed to be less alarmed about the pope's designs on America than about proslavery settlers' activities in Kansas. When the national Know Nothing convention in Philadelphia drafted what could be considered a proslavery platform, Clarke was dismayed but continued to work within the order for another eight months. But most Hawkeyes-including a great many Iowa Know Nothings-thereafter looked to the fledgling Republican party movement, not to the slaverytainted Know Nothings, for redress. As Know Nothing membership in Iowa fell off, local Republican conventions began to flourish, and the American party lost ground in the August 1855 elections. After that the Know Nothing press swung into line behind Republicanism. Iowa's American party convened to pass seven resolutions, only one of which reflected standard nativist concerns. The others expressed hostility to slavery. The state's Know Nothings, in effect, had offered the antiextensionists another fusion-if uneasily. "They are timid," cautioned Wells Spicer, who now considered himself a Republican, "-they have a misgiving about becoming a part and parcel of us in the coming campaign." ${ }^{21}$ Obviously, the Know Nothings would exact a price for their cooperation.

About 10 percent of the men who met in Iowa City in February 1856 to form a state Republican party were Know

20. Matthias, "Know Nothing Movement," 84-85; Daily Iowa State Gazette (Burlington), 29 February 1856, quoted ibid., 82-83n; Cedar County Advertiser (Tipton), quoted ibid., 94; William Lockridge to William Penn Clarke, 12 April 1856, Clarke Papers.

21. Matthias, "Know Nothing Movement," 95-116; Dykstra, Bright Radical Star, 131; Wells Spicer to William Penn Clarke, 11 November 1855, Clarke Papers. 
Nothings, on hand to help superintend a coalition. The main problem faced by the Republican delegates was how to coalesce with the American party without alienating Iowa's German-born voters, who were already upset about the new party's possible endorsement of liquor prohibition. The evidence for the fusion is not in the Republican platform, which said nothing about nativism, but in the four candidate nominations. In his highly regarded recent book on the origins of the nation's Republican party, William E. Gienapp concludes that friction over the Iowa nominations was nonexistent because "all officers to be elected in [August] were of limited importance." But the real reason there was no friction is that the Republican nominations were, by design, political payoffs to the Know Nothings. The convention's refusal to name William Penn Clarke for attorney general was the only hitch. It nominated reputed or admitted Know Nothings Elijah Sells for secretary of state, Martin L. Morris for state treasurer, and John Pattee for state auditor. A week later, the American party's state convention named the same men, and fusion was complete. ${ }^{22}$

But then it all came to naught. "The course that the Republican press is now taking will in my opinion destroy all hope of union," wrote one concerned observer. "The state ticket nominated by both parties they denominate the 'Republican' ticket, instead of claiming as the fact is, that it is a 'union' or 'peoples' ticket. ... If the Republicans consider it a union ticket they ought to say so, if not they can't expect the American party as a party to vote it." In the end, neither the national Know Nothings nor the Iowa Know Nothings permitted themselves to be co-opted for free soil. ${ }^{23}$

When the American party's national convention refused to condemn the Kansas-Nebraska Act and gave its presidential nomination to ex-President Millard Fillmore, widely detested in the North for having enthusiastically signed the

22. Dykstra, Bright Radical Star, 132-34; Gienapp, Origins, 279; Matthias, "Know Nothing Movement," 130-38. In its selections of delegates and other non-candidate spokesmen, Iowa's charter Republicans were more balanced, honoring its Know Nothing minority only at about the same frequency as it honored its former Free Soil party minority.

23. Lockridge to Clarke, 12 April 1856, Clarke Papers. 
notorious Fugitive Slave Law, Clarke helped lead an exodus of free-state delegates out of the convention. After that he had nothing more to do with the Americans. Then Iowa's Know Nothing remnant-in what Governor Grimes termed a "want of good faith \& ignorance of all political arithmetic" resolved in favor of Fillmore and the American party's national platform. Thereafter, Iowa's Republicans simply let the exciting events associated with the renewed guerrilla war in Kansas between Free Staters and Border Ruffians carry their party to victory. ${ }^{24}$

But the Know Nothings were not quite out for the count. In August 1856 yet another native southerner, the Alabamaborn physician John J. Selman of Bloomfield, ran for Congress on the Know Nothing ticket. He came in a very poor third with a mere 828 votes. In only nine of his district's thirty-six southern counties did anyone at all vote for Dr. Selman. Not surprisingly, he did his best-one-fifth of the ballots cast-in his own Davis County (table 1). That was the only multicounty election witnessing a direct face-off among Republican, Democratic, and Know Nothing nominees. Unfortunately, the meager and very unevenly distributed third-party vote precludes any plausible statistical analysis of it. $^{25}$

In the presidential election of November 1856, Iowa went for the Republican candidate, John C. Frémont, although the Democrat, James Buchanan, won the election nationwide. Fillmore, with a paltry 9,679 votes (10 percent of the total cast) came in a poor third. He won not a single county, although along the Missouri border he did quite well,

24. Grimes to Clarke, 3 April 1856, "Letters of James W. Grimes," Annals of Iowa 22 (1940), 475; Dykstra, Bright Radical Star, 135-36. For Clarke's own account of his role in the walkout after Fillmore's nomination, see the edited document later in this issue.

25. Edward H. Stiles, Recollections and Sketches of Lawyers and Public Men of Early Iowa (Des Moines, 1916), 688-89; Matthias, "Know Nothing Movement," 177-78. The official canvassing board's arithmetic was abominable in several instances, and Selman's total vote is incorrectly listed as 654 . Iowa Secretary of State, "Election Records" (microfilm copy, University of Iowa Libraries), reel 1. 
TABLE 1

THE KNOW NothING Vote IN SOUTHERN IOWA, August 1856:

ELECTORAL SUPPORT FOR JOHN J. SELMAN

\begin{tabular}{lrr}
\hline & Number & Percent \\
\hline Appanoose County & 58 & 4.5 \\
Davis County & 353 & 20.5 \\
Henry County & 114 & 5.0 \\
Jefferson County & 2 & .0 \\
Lee County & 174 & 4.6 \\
Lucas County & 113 & 18.3 \\
Mahaska County & 3 & .1 \\
Union County & 3 & 1.1 \\
Warren County & 2 & .1 \\
Wayne County & 6 & 1.0 \\
\hline
\end{tabular}

SOURCE: Iowa Secretary of State, "Election Records" (microfilm copy, University of Iowa Libraries), reel 1.

coming within three ballots of taking Page County - which at least one prominent historian incorrectly has him winning. ${ }^{26}$

But Millard Fillmore did much better than the American party's congressional candidate had done in the earlier August election. Ronald Matthias concludes, therefore, that "the vast majority of votes cast for Fillmore seem to have come not from still-active Americans, but rather from Democratic and Republican defectors (many of whom may very well have been Know Nothings in the past)." Statistical analysis of the election results mainly supports Matthias as to the Democrats. The 21,202 men who had opposed the Grimes coalition in 1854 had overwhelmingly rejected the Know Nothing/ Anti-Nebraska ticket in 1855. They split, however, in 1856, an estimated 31 percent of them defecting to the American candidate. Indeed, Democrats made up 70 percent of the support Fillmore drew from the 1854 electorate. Since these same pro-Fillmore Democrats had strongly opposed McKay, the Know Nothing-endorsed nominee in 1855, it is doubtful that many of them had once been Know Nothings. ${ }^{27}$

26. Matthias, "Know Nothing Movement," 197; James M. McPherson, Ordeal by Fire: The Civil War and Reconstruction (New York, 1982), 97 (map).

27. Matthias, "Know Nothing Movement," 177-79, 198; Dykstra, Bright Radical Star, 289 (table B.6); Gienapp, Origins, 537 (table 13.22). 
As for Republican defectors to Fillmore, Matthias is referring to men who had supported Republican candidates in the August 1856 election but who then might have voted November's American ticket. He argues that in several counties "there seems to be every reason to believe that had Fillmore not been a candidate, Frémont would have crushed Buchanan in Iowa even more triumphantly than was in fact the case." This supposition fails to hold up under statistical scrutiny. Table 2 tests the November behavior of the August 1856 electorate, but includes in the analysis only non-Know Nothings-specifically, returns from counties where nobody, or virtually nobody, had supported Selman. As indicated in the table, virtually all of those who had voted Republican in the August 1856 election voted for the Republican presidential candidate in November, and those Republican voters constituted 38 percent of the total eligible electorate in the counties analyzed. Most of the votes Fillmore did get came from those who had voted the Democratic ticket in August, even though most Democrats predictably favored Buchanan. ${ }^{28}$

In any event, Matthias is clearly correct that Fillmore's candidacy represented more than just nativism to Iowa's voters. Fillmore's Iowa handlers stressed the former president's alleged stature as the only man who could restore peace and tranquillity to the nation. As one supporter explained, "Mr. Fillmores Know Nothing proclivities I do not like but sir he is a Union man tried true and trusty.... I vote for my whole country not for a northern faction [the Republicans] or for a southern propagandist of slavery [Buchanan]." This statement reflects Fillmore's relative popularity along the Missouri border. It also suggests his appeal, as a former Whig, to Iowa's "old line" Whigs: an estimated 29 percent of the men who

28. Matthias, "Know Nothing Movement," 201. In setting up the analyses, I deemed it unnecessary to compute the "ineligibles" of August 1856 because the August and November elections were chronologically so close as to make the two electorates very similar in size. Also, no other aspect of the August election suggested the need for any additional measure of statistical precision. (For a discussion of the normal requirement for such calculations, see Dykstra, Bright Radical Star, 284.) Similarly, I let November's estimate of eligible voters serve as a surrogate for the estimated eligible voters of August. 
TABLE 2

How the August 1856 Electorate Behaved IN November $1856^{\mathrm{a}}$

\begin{tabular}{|c|c|c|c|c|c|}
\hline & $\begin{array}{l}\text { Frémont } \\
\text { (R) }\end{array}$ & $\begin{array}{l}\text { Buchanan } \\
\text { (D) }\end{array}$ & $\begin{array}{c}\text { Fillmore } \\
\text { (A) }\end{array}$ & $\begin{array}{c}\text { Not } \\
\text { voting }\end{array}$ & \\
\hline Republicans & 38 & 0 & 0 & 0 & \\
\hline Democrats & $-4^{b}$ & 30 & 6 & 2 & \\
\hline \multirow[t]{2}{*}{ Nonvoters } & 10 & 5 & 1 & 15 & \\
\hline & & & & & $103^{c}$ \\
\hline
\end{tabular}

SOURCE: Iowa Secretary of State, "Election Records" (microfilm copy, University of Iowa Libraries), reel 1.

'Estimated percentages. Appanoose, Davis, Henry, Lee, and Lucas counties are excluded from the analysis. Regressions: 1856 congresssional returns $\times 1856$ presidential returns (county $\mathrm{N}=72$ ).

bBecause the tabulated percentages are computer-generated estimates, they can (with perfect statistical logic) come out less than zero. Thus this -4 percentage should be considered a particularly emphatic zero.

The total is more than 100 due to rounding error.

had voted Whig in the 1852 presidential election cast their votes for Fillmore four years later. ${ }^{29}$

No single group in the political population went heavily for Fillmore. Transplanted Pennsylvanians exhibited the oddest behavior, spreading their votes fairly evenly among Frémont, Buchanan, and Fillmore. Presumably Buchanan, a Pennsylvanian, drew votes from Frémont, accounting for the spread; twelve years later these same Pennsylvanians went heavily Republican. Slave-state natives (no surprise) gave Fillmore his largest Iowa percentage, even though twice as many of these transplanted southerners supported Buchanan. Of religious groups, Methodists from southern Iowa provided Fillmore's largest percentage, although most of them voted Democratic. The mainly southern-born Disciples of Christ split their ballots between Buchanan and Fillmore. Of discernable economic groups, none gave a majority to Fillmore. ${ }^{30}$

29. Matthias, "Know Nothing Movement," 182-85, 187-88; W. C. Stanberry to the Vinton Eagle, 10 September 1856, quoted ibid., 187n; Dykstra, Bright Radical Star, 289 (first panel of table B.7).

30. Dykstra, Bright Radical Star, 257 (table 12.11), 289-90 (third, fourth, and fifth panels of table B.7). By the 1850 s, Iowa's Methodists had split (purely for organizational convenience) into upstate and downstate conferences. Methodists of the northern Iowa conference gave an estimated majority of their votes to Frémont. See ibid., 146, 275. 
THE KNOW NOTHING EPISODE in Iowa had little lasting effect on public policy. For example, two self-identified members of the order sat in the 1856-57 Iowa General Assembly. Virginia-born senator George W. Wilkinson, a Methodist bricklayer from Muscatine, introduced no bills into the upper chamber, held only one standing committee assignment (on the largely inactive Committee on County Boundaries), never won appointment to any select committee, and appears to have cast his votes mainly with the Republicans. Ohio-born representative Thomas Sawyer, a Lee County farmer and active Presbyterian, introduced no bills or resolutions into the House. He did serve as chairman of the Committee on Agriculture, which handled controversial mill regulation and herd law issues, but was otherwise a member only of a committee charged with establishing a state library. Neither Wilkinson nor Sawyer apparently continued active in Hawkeye politics. ${ }^{31}$

Despite the end of organized nativism, the Iowa Republicans' challenge through the late 1850 s was to continue extending a quiet welcome to ex-Know Nothings while remaining openly congenial to the German-born. As U.S. Senator James Harlan put it, "We must keep Iowa in line. This will require wise counsels and discreet action. We have a large American vote in the southern counties, and a large foreign element in all the counties bordering on the Mississippi river. We cannot afford to lose either." The former task was far easier than the latter. With respect to Iowa, at least, one cannot convincingly deny William Gienapp's conclusion that switching allegiance from the American to the Republican party required little deep soul-searching. Iowa's German Republicans, on the other hand, remained uneasy, always ready to bolt when they suspected that the party's anti-liquor wing was gaining ascendancy. ${ }^{32}$

31. T. D. Eagal and R. H. Sylvester, The Iowa State Almanac and Statistical Register for 1860 (Davenport, 1860), 23; 1857 Iowa Senate Journal, 20, 35859, 593, 621-22; The History of Lee County, Iowa (Chicago, 1879), 764; 1857 Iowa House Journal, 32-33, 84, 137-38, 161, 222, 309, 323-24, 62526, 657-62.

32. James Harlan to William Penn Clarke, 23 May 1856, Clarke Papers; William E. Gienapp, "Nativism and the Creation of a Republican Majority 
A more specifically nativist issue soon emerged with passage in Republican-dominated Massachusetts of a "two-year amendment" requiring immigrants to wait twenty-four months after naturalization to vote. In the face of German outrage, Iowa's Republican party easily finessed the issue, its top leadership condemning the Massachusetts law and nominating the law's bitterest Iowa critic, Davenport's Germanborn Nicholas J. Rusch, as their candidate for lieutenant governor in 1859. And, importantly, as one Republican spokesman put it, "Our Know Nothing [the] Hon. James Thorington was one of the most effective laborers for the nomination of Mr. Rusch." 33

Finally, what eventually happened to Iowa's leading Know Nothings? Matthias thinks their past did not politically hurt them. I am not altogether sure. Frank W. Palmer, very prominent as editor of the Iowa State Register in Iowa's postCivil War politics, had been a leading Know Nothing-but back in New York State, not in Iowa. ${ }^{34}$ James Thorington and William Penn Clarke appear to have been effectively frozen out of the Republican party's higher circles once their usefulness in attracting and holding former Know Nothings came to an end. Bloomfield's James B. Weaver became a prominent Republican, but had to seek major office on maverick, thirdparty tickets; his claims to fame rest with his national Greenback and Populist presidential nominations. Knoxville's William M. Stone, a prominent Know Nothing editor, later served two terms as Iowa's governor. But his initial Republican nomination was always considered by party regulars to have been a fluke, and-despite his politically heroic role as a campaigner for civil rights in 1865-Stone found himself shut out of Republican politics once his second term came to

in the North before the Civil War," Journal of American History 72 (December 1985), 547.

33. Rosenberg, Iowa, 183-87, 192-94; [John?] Teesdale, quoted in F. I. Herriott, "The Germans of Iowa and the 'Two-Year' Amendment of Massachusetts," Deutsch-Americanische Geschichtsblätter 13 (1913), 304.

34. Anbinder, Nativism and Slavery, 274. Palmer's initial Iowa editorship was at the Dubuque Times. For his continuing nativist attitudes in 1859, see Herriott, "Germans of Iowa," 216-17, 234. 
an end. ${ }^{35}$ Maybe this political fallout was the most lasting effect of Iowa's short-lived, unlamented Know Nothingism of the 1850 s.

35. Matthias, "Know Nothing Movement," 183, 206-7, 219; Dykstra, Bright Radical Star, 202, 212-14, 239. Admittedly, no firm evidence exists respecting the exclusion of former Know Nothings from important positions within the Republican party. Clarke and Stone were both considered "opportunists," for example, but this is not very plausible as an alternate explanation for their fate. A writer who knew Stone well tries to decode the political bias against him, but is not very convincing. Stiles, Recollections and Sketches, 76-78. 
Copyright of Annals of Iowa is the property of State of Iowa, by \& through the State Historical Society of Iowa and its content may not be copied or emailed to multiple sites or posted to a listserv without the copyright holder's express written permission. However, users may print, download, or email articles for individual use. 